\title{
New White House science council
}

\section{Physics looms large on advisory panel}

\section{Washington}

Dr Jay Keyworth, President Reagan's Science Advisor, announced last week that he is setting up a new White House Science Council to advise him on "science and technology issues of national concern" and of "changing perspectives in the science and technology communities",

The thirteen members of the new council will carry out tasks similar to those of the President's Science Advisory Committee (PSAC), which was abolished by President Nixon in 1973. However, unlike PSAC, which reported directly to the president, the council will report to Dr Keyworth as director of the Office of Science and Technology Policy.

Dr Keyworth in turn reports to the president's chief-of-staff in the White House, Mr Edwin Meese, implying a lower status to the Science Advisor's job than in previous administrations. So the Science Council, which is also distinct from the commission proposed by Congress in the Science and Technology Policy Act of 1976, will probably enhance $\mathrm{Dr}$ Keyworth's position on key policy issues.

The council, already being referred to as WHSC (or "wissick"), will therefore perform many of the functions of the President's Science Advisory Committee, established by President Eisenhower in 1957 in response to the launching of the Russian sputnik, and abolished by President Nixon in 1973 when some of its members took a public stand against his policies on anti-ballistic missiles and supersonic aircraft. But officials at the Office of Science and Technology Policy (OSTP) emphasize that whereas the committee formally reported directly to the president, WHSC will report to Dr Keyworth, OSTP's director.

There was no official comment on the balance of academic interests of the members of the new council, with its heavy emphasis on physics and the "hard sciences", and, apart from Dr Donald Fredrickson, the former director of the National Institutes of Health, no expert from the life or social sciences.

It was stressed, however, that individuals had been selected as much for their broad perspective and judgement on science policy questions as for their particular areas of expertise, and that each member had been hand-picked by Dr Keyworth "after a considerable amount of deliberation".

"We were concerned to have persons who can deal with the range of issues that we understand to be the greatest interest to this office," said OSTP staff member Dr Thomas H. Johnson, who will act as the executive director of the new council.

The chairman of the council will be $\mathrm{Dr}$ Solomon J. Buchsbaum, executive vicepresident of Bell Laboratories in New Jersey. Dr Buchsbaum is a plasma physicist by training, and is an experienced governmental science adviser, having acted as chairman of the Defense Science Board under President Ford, and chairman of the Department of Energy's Energy Research Advisory Board under President Carter.

Vice-chairman will be Dr Edward Frieman, also a plasma physicist and a vicepresident of the La Jolla-based consulting firm Science Applications Inc. Dr Frieman served as director of the Department of Energy's Office of Energy Research during the second half of the Carter Administration, and before that was deputy director of the Plasma Physics Laboratory at Princeton University.

Like Dr Buchsbaum and several other members of the new council, Dr Frieman has worked extensively as a scientific consultant to the Department of Defense.

\section{Keyworth irked}

One of the first jobs for the White House Science Council will be to hammer out a policy for the national laboratories supported by a federal government. And, according to Dr George A. Keyworth, President Reagan's Science Advisor, the national laboratories must be reorganized so as to provide more support for universities on the one hand and for United States industry on the other.

Dr Keyworth was speaking in London at the annual lunch of the Parliamentary and Scientific Committee, a regular event in the social calendar frequently used by British politicians to make promises or threats to their own scientific community. $\mathrm{Dr}$ Keyworth's irritation with the US national laboratories, made conspicuous by the blandness of the remainder of his speech, may cause managers of similar laboratories in Britain to fear that their own paymasters would follow Dr Keyworth's hint.

Dr Keyworth said that the original missions of United States national laboratories are frequently outdated, and that the "many billions of dollars" they receive from the federal government are not all used to "further fundamental knowledge or to address technologies pertinent to our national goals". He said that the laboratories have been "subject only superficially to external review" and that their missions had only rarely been reexamined.

Yet, according to Dr Keyworth, the national laboratories have a logical role as centres for cooperative research involving
The military connection is also illustrated by the links which several members have with the Department of Energy's Los Alamos National Laboratory in New Mexico, where Dr Keyworth spent most of his professional career as a physicist before going to Washington last May.

Dr Harold Agnew, for example, was a member of the original Manhattan Project team that worked on the atomic bomb at Los Alamos. He joined the laboratory in 1942 , became a director in 1970 , and left to become president of General Atomic in 1978.

Dr Edward Teller, now emeritus professor of physics at the University of California and widely known as "the father of the hydrogen bomb", also worked at Los Alamos between 1943 and 1946, and acted as assistant director of the laboratory between 1949 and 1953. Dr George Cowan, a senior fellow at the laboratory, is a radiochemist specializing in nuclear reactions who, like Teller, worked at the University of Chicago before moving to Los Alamos in 1949.

According to a formal notice which appeared in last Thursday's edition of the Federal Register, the council will have a

\section{by national labs}

universities and could even help to make good shortages of teachers of engineering and computer science. He also wants the national laboratories to help reduce the present "unacceptably high resistance" to the application of research.

For the rest, Dr Keyworth gave his somewhat bemused audience a self-congratulatory account of how research and development, and federal support for basic research in particular, were second only to defence in the protection they had enjoyed in the two Reagan budgets. Nevertheless, he said, the scientific community would have to accept a greater degree of discrimination - and more responsibility for making discriminatory judgements.

On international collaboration, Dr Keyworth said that the United States had come to realize the limitations of what it could accomplish on its own, and the opportunities for collaboration with Europe and Japan. He thought that the next generation of high-energy accelerators would have to be built collaboratively, and that there were already opportunities for broadening the base of thermonuclear research programmes, at present too exclusively dependent on tokamak designs.

Although Dr Keyworth did at one point emphasize that he was not to be mistaken for Mr David Stockman, director of the Office of Management and Budget, he left many of his audience with the impression of a man still preoccupied with the small print of resource allocation. 